\title{
Penicillinase-producing Neisseria gonorrhoeae among prostitutes in Surabaya
}

\author{
HENDRO SASTROWIDJOJO* AND ATASIATI IDAJADI† \\ From the ${ }^{*} C D C$ Surabaya Municipality Health Service and the +Department of Microbiology, Airlangga \\ University, Surabaya, Indonesia
}

SUMMARY Thirty-six strains of penicillinase-producing Neisseria gonorrhoeae (PPNG) were detected among 794 prostitutes between October 1981 and May 1982 in Surabaya, Indonesia. The high prevalence of PPNG strains among the high-class prostitutes and a lower prevalence among the low-class suggest that regular mass treatment for syphilis did not play an important role in the emergence and spread of PPNG; the importation of PPNG strains from abroad is more likely to have been responsible.

\section{Introduction}

Since the discovery of penicillinase-producing strains of Neisseria gonorrhoeae (PPNG) in 1976 in England and in the USA, ${ }^{1}$ infections with PPNG strains have been reported from many countries. The indiscriminate and suboptimal use of the penicillins may have caused and maintained the existence of PPNG strains. ${ }^{23}$ The first cases of PPNG infections in Indonesia were reported from Jakarta in 1980 and from Surabaya in $1981 .{ }^{4}$

Culture for $N$ gonorrhoeae is not performed routinely in Indonesia and contact tracing of infected individuals is not undertaken. As prostitutes are the major source of sexually transmitted diseases in Indonesia annual screening of these women is important in assessing the spread of PPNG strains in the community. About $85 \%$ of patients with gonorrhoea and non-gonococcal urethritis attending health centres in Surabaya named prostitutes as their source of infection. ${ }^{5}$

There are three classes of prostitute in Surabaya: the high-class, the local, and the clandestine prostitutes. The local prostitutes are the largest group, numbering about 5000; they live and operate in four districts and are registered semi-officially with the police. Socioeconomically they belong to the lower and middle classes. About 400 women who operate in two different streets in two districts have a much higher standard of living, demand a higher fee,

Address for reprints: Dr A Idajadi, Department of Microbiology, Medical Faculty, Airlangga University, Surabaya, Indonesia

Accepted for publication 23 October 1982 and can be classified as high-class local prostitutes; their clients are usually middle-class men. Since 1958 compulsory regular mass treatment consisting of a weekly injection of 900000 units of penicillin in oil has been given to the local prostitutes. This has effectively lowered the incidence of syphilis among prostitutes. Serological tests for syphilis were positive in the sera of $86.6 \%$ of female prostitutes in 1955; at present only $4 \%$ have treponemal antibodies in their serum. ${ }^{56}$

High-class prostitutes consist of call-girls operating in several private houses and girls working in massage parlours. Their clients are mostly upper middle-class men of the local community and foreigners. The callgirls attend their own doctors irregularly whereas the massage girls are examined weekly by the company doctors who examine Gram-stained vaginal smears. There are about 300 high-class prostitutes and they frequently treat themselves.

The clandestine prostitutes are low-class women who operate on the streets during the night; their clients are usually from the lower classes of the community. Twice a month they are treated with $2 \cdot 4$ million units of benzathine penicillin.

Several surveys among these prostitutes in 1976, 1977, and 1979 failed to detect PPNG strains. ${ }^{7}$ After three cases of PPNG infection in Surabaya were reported ${ }^{4}$ a survey of gonococcal infection among prostitutes was undertaken in 1981.

\section{Patients and methods}

Between October 1981 and May 1982, 694 prostitutes were examined for infection with $N$ gonorrhoeae. Of these, 133 were call-girls, 107 massage girls, 268 local 
prostitutes, 100 high-class local prostitutes, and 86 clandestine prostitutes. The 368 local prostitutes were selected at random from all the red light districts. The clandestine prostitutes were examined after being taken from the streets by the local authorities. The call-girls and massage girls attended for routine examination (see above).

Material for culture was taken from the urethra, the cervix, the pharynx, and the rectum in each woman. The specimens were inoculated directly on to modified Thayer-Martin medium (Oxoid, UK) and incubated in a candle jar at $37^{\circ} \mathrm{C}$ for 48 hours. $N$ gonorrhoeae was identified by colonial morphology, microscopic examination of Gram-stained smears, oxidase reaction, and sugar fermentation tests. ${ }^{89}$ The penicillin sensitivity of each isolate was tested by the disc diffusion method using a 10-unit penicillin G disc. When micro-organisms showed resistance to penicillin $G$ they were tested for penicillinase production by the starch-iodine test. ${ }^{12}$

\section{Results}

Of the 694 prostitutes, $266(38 \cdot 3 \%)$ were infected with $N$ gonorrhoeae: the number infected with PPNG strains are given in table I and the sites from which the strains were isolated in table II. All strains of PPNG were resistant to penicillin G.

TABLE I No of prostitutes infected with penicillinaseproducing $N$ gonorrhoeae (PPNG) strains

\begin{tabular}{llll}
\hline Group & $\begin{array}{l}\text { Total } \\
\text { No }\end{array}$ & $\begin{array}{l}\text { No with } \\
\text { gonorrhoea }\end{array}$ & $\begin{array}{l}\text { No infected with } \\
\text { PPNG strains }\end{array}$ \\
\hline Call-girls & 133 & 46 & 11 \\
Massage girls & 107 & 28 & 4 \\
$\begin{array}{l}\text { Local prostitutes } \\
\text { High-class local } \\
\begin{array}{l}\text { prostitutes } \\
\text { Clandestine }\end{array}\end{array}$ & 268 & 122 & 6 \\
prostitutes & 100 & 45 & 15 \\
\hline
\end{tabular}

TABLE II Sites of infection with $N$ gonorrhoeae

\begin{tabular}{lcc}
\hline Sites & $\begin{array}{l}\text { No (\%) of women } \\
\text { with positive } \\
\text { cultures }\end{array}$ & $\begin{array}{l}\text { No (\%) of isolates } \\
\text { producing } \\
\text { penicillinase }\end{array}$ \\
\hline Pharynx & $65(9 \cdot 4)$ & $3(4 \cdot 6)$ \\
Rectum & $80(11 \cdot 5)$ & $8(10 \cdot 0)$ \\
Urethra & $144(20 \cdot 8)$ & $19(13 \cdot 2)$ \\
Cervix & $136(19 \cdot 6)$ & $25(18 \cdot 3)$ \\
Total & $425(46 \cdot 8)$ & $55(16 \cdot 9)$ \\
\hline
\end{tabular}

\section{Discussion}

Regular mass treatment has been the policy for the control of syphilis in Indonesia since 1957. Those who opposed this policy argued that although this had reduced the incidence of syphilis it might increase the resistance of $N$ gonorrhoeae to penicillin if it was given in suboptimal doses. As strains of PPNG have been identified in many countries around Indonesia it was feared that regular mass treatment might produce an increase in the prevalence of PPNG infections among the local prostitutes. The absence of PPNG in the prostitutes in the 1976, 1977, and 1979 surveys compared with the present results, which showed a high prevalence of PPNG among the high-class prostitutes and the high-class local prostitutes and a low prevalence among the general local prostitutes, suggested that regular mass treatment did not precipitate the spread of PPNG. A more likely explanation for the increased prevalence of PPNG among the high-class prostitutes is the importation of PPNG strains from abroad. As penicillin has been the treatment of choice in the health centres in Surabaya the discovery of PPNG strains among the prostitutes has created a problem in the treatment of gonorrhoea. Further studies are needed to assess the effect of epidemiological treatment of prostitutes and the recommendation for the treatment of gonorrhoea will require revision.

\section{References}

1. World Health Organisation. Neisseria gonorrhoeae producing penicillinase. WHO Weekly Epidemiological Record 1976;51: 293-4.

2. World Health Organisation. Neisseria gonorrhoeae producing $\beta$-lactamase (penicillinase). WHO Weekly Epidemiological Record 1976;51:385-6.

3. World Health Organisation. Neisseria gonorrhoeae producing $\beta$-lactamase (penicillinase). WHO Weekly Epidemiological Record 1977;52:357-9.

4. Soendjojo A, Idajadi A, Barakbah J, Ilias MI. Penicillinaseproducing Neisseria gonorrhoeae isolated in Surabaya. Br J Vener Dis 1981;57:376-7.

5. Surabaya Municipality Health Service. Annual Report 1979/80.

6. CDC Directorate General. Prevention and Control of Venereal Diseases. Republic of Surabaya: Ministry of Health, 1970.

7. Antimicrobics Investigation Section, Center for Disease Control. Rapid Laboratory Tests for Beta-lactamase Production by Bacteria. Washington DC: US Department of Health, Education and Welfare, 1977.

8. Douglas S, Kellogg JR. Neisseria gonorrhoeae (gonococcus). In: Lennette EH, Spaulding EH, Truant JP, eds. Manual of Clinical Microbiology, 2nd ed. Washington DC: American Society for Microbiology, 1974:124-9. 